\title{
Web Day in Portland, Oregon
}

On July 14, 1995, while all of France was celebrating Bastille Day, library staff in the Portland, Oregon, area were celebrating Web Day, a full day of workshops dealing with various aspects of the World Wide Web. This event was sponsored by PORTALS, the Portland Area Library System.

PORTALS was established in 1993 to provide improved library and information services to the Portland metropolitan area. Members include twelve academic libraries, one public library system, and the Oregon Historical Society. Users enjoy access to 21 databases and improved access to member collections. Access is available through direct Internet connections and modem dialup. The State of Oregon and membership dues provide PORTALS' funding.

Web Day featured introductory and keynote sessions attended by all participants, followed by five focused breakout sessions and a lab equipped with personal computers running Netscape and staffed with volunteers. Municipal and state government representatives, as well as Portland area library staff attended Web Day.

\section{ALA holds information literacy hearing at Midwinter}

ALA's User Instruction for Information Literacy Committee invites interested members to a hearing to determine the need for the committee on Monday, January 22, 2:00-4:00 p.m., at the ALA Midwinter Meeting in San Antonio. The committee stated it had difficulty carrying out its charge to "review and coordinate . . a activities within ALA regarding instruction for users in acquiring, or organizing, information ... to encourage association-wide programming.

Cited reasons for the difficulty include lack of formal representation from other ALA groups involved in information literacy and the fact that those other ALA units are carrying out the programmatic activities.

\section{Harvard and MIT sign reciprocal access agreements}

Representatives of the Harvard College Library and MIT Libraries signed an agreement on July 24 establishing reciprocal library privileges for
The introduction presented by Millard Johnson of PORTALS, "The Web, PORTALS, and the Virtual Library," challenged the audience to consider the implications of a Virtual Library independent of traditional institutional identity. Gary Sampson of Portland State University delivered the keynote address, "The World Wide Web," in which he provided an overview of the Web's history, its present state. and speculations about its future.

Breakout sessions included "'Cool' Sites," which explored selected Web sites noteworthy for their wide appeal and usefulness; "Home Setups," which investigated the technological and financial issues involved in setting up a Web browser on a home computer. A "Netscape/Lynx" workshop covered the essential "how to" elements of navigating the Web. There was a "Creating Web Pages" session, as well as a "Spiders, Crawlers and Other Wondrous Things" workshop which compared various search engines.

Plans are under way to repeat Web Day this winter for those unable to attend the first one.-Rbona Klein, Portland State University; e-mail: rbona@godzilla.lib.pdx.edu

many members of the MIT and Harvard communities. The agreement, which went into effect on September 1, establishes closer relations between two schools that historically have had strong connections. It also follows the trend of academic libraries creating alliances with peer institutions to expand their resources in a costeffective way.

Richard De Gennaro, Roy E. Larsen librarian of Harvard College, said, "I think this agreement will be advantageous to both schools, and I expect it will lead to other forms of library cooperation in the future."

\section{"Rettig on Reference" debuts on the Internet}

"Rettig on Reference," a free service sponsored by the $\mathrm{H}$. W. Wilson Co., provides reviews of new reference books and Internet-based reference sources. As was the case when Jim Rettig was the reference book reviewer for the now defunct Wilson Library Bulletin, he writes all of the reviews. According to Rettig, "I have 